\title{
ACRL at ALA National Library Legislative Day
}

On April 30, 2001, more than 60 academic librarians met in Washington, D.C., to share lunch, acquire information about legislative issues, and pick up advocacy strategies. The ACRL Legislative Luncheon was held during the ALA National Library Legislative Day, an event that raises awareness about the importance of federal funding for libraties. This is the third year that ACRL has sponsored a luncheon at National Library Legislative Day.

The luncheon program consisted of knowledgeable speakers who addressed specific legislative issues of importance to academic libraries. Charles Beard, director of libraries at the State University of West Georgia, moderated the discussion and updated the attendees on the Children's Internet Protection Act (CIPA). Although CIPA primarily affects school and public libraries, Beard explained that it also has the potential to affect academic libraries.

Another important legislative issue discussed at the luncheon was the Uniform Computer Transactions Act (UCITA). Rodney Petersen, director of policy and planning at the Office of Information Technology at the University of Maryland, spoke to the attendees about his experiences fighting UCITA in Maryland. Although National Library Legislative focuses on federal issues and UCITA is an act being introduced at the state level,
Petersen told the audience that this luncheon was a good opportunity for academic librarians to learn about this act and share their experiences with UCITA. Carol Ashworth, the UCITA grassroots coordinator with the ALA Washington Office, was also on hand to answer librarians' questions.

The final luncheon speaker, ACRL Executive Director Althea H. Jenkins, encouraged attendees to talk to their representatives about supporting the reauthorization of the Library Services and Technology Act (LSTA), the oniy federal program exclusively for libraries. She reminded the andience that the LSTA leadership grants fund innovative programs in academic libraries throughout the country.

Several of the attendees commented on the importance of having this type of event to encourage academic librarians to take a bigger role in advocating on behalf of their libraries.

ACRL will build on the success of this and previous Legislative Luncheons by encouraging even more academic librarians to attend this event and all of the activities at next year's ALA National Library Legislative Day.-Shannon Cary, AGRL director of Research and Special Initiatives, scary@ala.org to allow users to instantly access a program directly from the libraries' online catalog.

He added: "Digital video-on-demand systems have been a reality for a number of years, but copyright and intellectual property constraints have made most academic institutions reluctant to purchase expensive video server technologies. Universities were faced with a classic dilemma: if we purchase a server, will we be able to find video programming we can legally put on the system? This agreement answers that question with a resounding "yes'?"

The UMD Libraries expect to launch a pilot project in the fall, enabling users to access a limited number of titles in the collection, according to Jeff Bridgers, head of Digital Libraries.

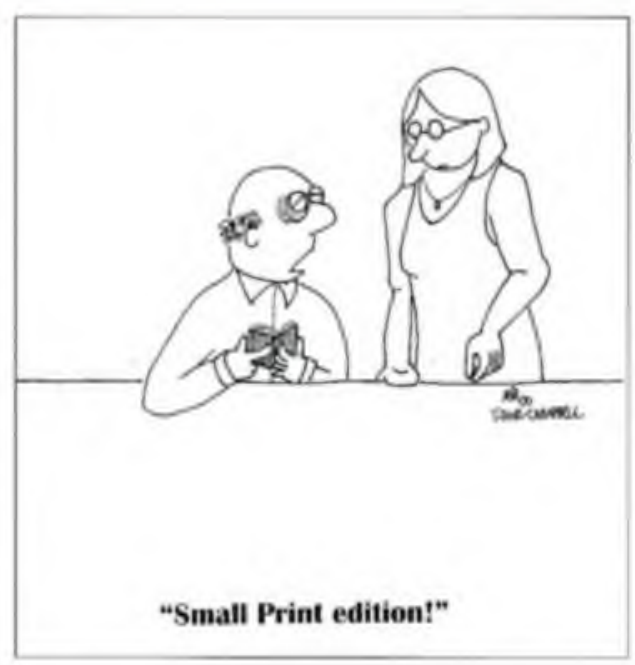

